\title{
Impact of competitions for ideas and business plans on firm creation and development of entrepreneurial university: case study of the IPC in Portugal
}

João P. C. Marques ${ }^{1,2}$

\footnotetext{
Correspondence: jmarques@iscac.pt 'Polytechnic Institute of Coimbra, ISCAC, Quinta Agrícola - Bencanta, 3040-316 Coimbra, Portugal 2Department of Economics, Management and Industrial Engineering, Research Unit on Governance, Competitiveness and Public Policies, University of Aveiro Campus de Santiago, 3810-193 Aveiro, Portugal
}

\begin{abstract}
The phenomenon of the entrepreneurial university has received considerable attention in recent decades, since the entrepreneurial orientation of academia could put regions and nations at an advantage in areas of economic activity where the focus is on emerging knowledge. Empirical research on entrepreneurial initiative incentives within universities and involving students and lecturers is scarce. This article examines the impact of competitions for ideas and business plans on start-up creation and patent registration, given the involvement of lecturers, the existence of $R \& D$ underpinning the idea and the technological area. The data used refer to 20 business ideas finalists in competitions between 2008 and 2014 at the Polytechnic Institute of Coimbra. The results show that these incentives have a significant impact on firm creation and patent registration and that the ideas and business plans competitions are important instruments to encourage the entrepreneurial spirit in an academic environment, motivating students and lecturers.
\end{abstract}

Keywords: Entrepreneurial universities, Firm creation, Entrepreneurship, Triple helix JEL Classification: M13, L26

\section{Resumen}

El fenómeno de la universidad empresarial ha recibido abundante atención en las últimas décadas ya que la orientación emprendedora de la academia podría dar una ventaja económica a regiones y naciones. En particular, esta ventaja se verá en los sectores centrales de la economía del conocimiento. Sin embargo, la investigación empírica sobre los incentivos para estudiantes y profesores es escasa.

En este artículo se analiza el impacto de los concursos de emprendimiento sobre la creación de empresas y sobre el registro de patentes, en un contexto en el que existe buena participación de profesores y suficiente investigación sobre la tecnología a comercializar. Se usan datos de 20 finalistas de estos concursos entre 2008 y 2014 en el Instituto Politécnico de Coimbra. Los resultados muestran que estos concursos tienen un impacto significativo en la creación de empresas y el registro de patentes. Asimismo, la formulación de ideas y planes de negocios motivan a estudiantes y profesores y son por tanto buenos incentivos para fomentar el espíritu emprendedor en el ámbito académico.

\section{Springer}

(c) 2016 Marques. Open Access This article is distributed under the terms of the Creative Commons Attribution 4.0 International License (http://creativecommons.org/licenses/by/4.0/), which permits unrestricted use, distribution, and reproduction in any medium, provided you give appropriate credit to the original author(s) and the source, provide a link to the Creative Commons license, and indicate if changes were made. 


\section{Résumé}

Le phénomène de l'université entrepreneuriale a considérablement retenu l'attention ces dernières décennies, étant donné que l'orientation entrepreneuriale du monde académique pourrait procurer des avantages aux régions et aux nations dans le domaine des activités économiques où l'accent est mis sur les nouveaux savoirs. La recherche empirique sur les incitations à l'initiative entrepreneuriale au sein des universités, impliquant enseignants et étudiants, est rare. Cet article examine l'impact des compétitions d'idées et de plans d'affaires sur la création de start-up et l'enregistrement de brevets, tenant compte de la participation des enseignants, de l'existence de la R\&D sous-tendant l'idée et du domaine technologique. Les données utilisées se rapportent aux 20 idées d'affaires finalistes des compétitions entre 2008 et 2011 à l'Institut Polytechnique de Coimbra (IPC). Les résultats montrent que ces incitations ont un impact significatif sur la création d'entreprises et l'enregistrement de brevets, et que les compétitions d'idées et de plans d'affaires sont des instruments importants pour encourager l'esprit d'entreprenariat dans un environnement académique et motiver les étudiants et les enseignants.

\section{摘要}

近几十年来创业型大学现象已经受到相当大的关注,因为学术界的创业导向能使 区域和国家在经济活动领域获得优势，重点在最新出现的知识。目前对于高校内 部师生创业激励机制的实证研究还非常贫乏。本文鉴于教师参与、支撑想法的 研发的存在和技术领域,探讨想法竞赛和商业计划对于高技术新创公司和专利注 册的影响。所使用的数据涉及科英布拉理工学院 (IPC - Instituto Politécnico de Coimbra )在2008-2014年间的想法竞赛中入围的20个商业想法。研究结果表 明,这些激励措施对公司创建和专利注册具有显著的影响, 而想法和商业计划是在 学术环境中鼓励创业精神和激励师生的重要手段。

\section{Аннотация}

феномен предпринимательского университета привлекает значительное внимание в последние десятилетия, поскольку ориентированность научного сообщества в сторону бизнеса может обеспечить регионам и странам преимущества в экономических сферах, связанных с генерацией знаний. Эмпирические исследования, посвященные стимулированию предпринимательских инициатив в университетах с участием студентов и преподавателей, довольно редки. Настоящая статья исследует влияние конкурсов идей и бизнес-планов на создание стартапов и регистрацию патентов, учитывая вовлечение преподавателей, текущую интенсивность исследований и разработок в определенной области знаний. Исходные данные включают информацию о 20 финалистах конкурсов бизнес-идей, проводившихся в период с 2008 по 2014 годы в Политехническом Институте Коимбра. По результатам исследования был сделан вывод о том, что указанные инициативы имеют существенное влияние на создание фирм и регистрацию патентов, а также то, что подобные конкурсы идей и бизнес-планов являются важными инструментами стимулирования духа предпринимательства в академической среде, мотивируя студентов и преподавателей. 


\section{Resumo}

O fenômeno da universidade empreendedora tem recebido atenção considerável nas últimas décadas, desde de que a orientação empreendedora na universidade coloca regiões e nações em vantagem em áreas de atividade econômica onde o foco é sobre conhecimento emergente. Pesquisas empíricas sobre iniciativas empreendedoras incentivadas dentro de universidades e envolvendo alunos e professores é escassa. Este artigo examina o impacto dos concursos de ideias e planos de negócios na criação de start-ups e no registro de patentes, dado o envolvimento de professores, a existência de P\&D subjacente à ideia e a área tecnológica. Os dados utilizados referem-se às 20 ideias de negócio finalistas nas competições realizadas entre 2008 e 2014, no Instituto Politécnico de Coimbra. Os resultados mostram que esses incentivos tem um impacto significativo na criação de firmas e registro de patentes, e que os concursos de ideias e os planos de negócio são instrumentos importantes para encorajar o espírito empreendedor em um ambiente acadêmico, motivando os estudantes e os professores.

\section{Multilingual abstract}

Please see Additional file 1 for translation of the abstract into Arabic.

\section{Introduction}

The university is an institution with a long history that has gone through several stages in its development. Although initially conceived as an institution with an educational mission, universities later came to be sources of knowledge generation (R\&D). In recent years, they have taken on a third mission by contributing more directly to society and economic development (Etzkowitz and Leydesdorff 2000). This process has been conceptualised in different ways: for example, as a change in the "social contract" between university and the state (Guston and Keniston 1994), as a change between the modes of knowledge production (Gibbons et al. 1994) or as a result of the dynamics of the triple helix (Etzkowitz and Leydesdorff 1996).

In any case, the "capitalisation of knowledge" has proved to be the heart of a new mission for universities (Etzkowitz et al. 2000), linking academia more strongly with users of knowledge and establishing universities as economic players in their own right. According to Etzkowitz (2008), this entrepreneurial university rests on four pillars: (1) academic leadership able to formulate and implement a strategic vision; (2) legal control of academic resources, including ownership of tangible assets such as buildings and intangible ones such as intellectual property emanating from research; (3) organisational capacity for the transfer of technology through patents and firm creation, licensing and incubation; (4) entrepreneurial culture among administrators, lecturers and students.

Going considerably further than the production of knowledge and education, modern entrepreneurial universities seek practical applications for their discoveries to enhance social development. Universities are thus natural incubators which provide a framework to support lecturers and students in their efforts to start new ventures (Taylor 2012; Levi 2014). It is also a fertile ground for new scientific fields and new industrial sectors through crossfertilisation of ideas (Martinelli et al. 2008). In addition to these natural entrepreneurial characteristics, entrepreneurial universities explicitly take the lead in the development and allocation of knowledge/technology in the society and the economy. 
Academia traditionally identifies areas of research and teaching on which to focus the critical mass of excellence to attract external support and resources. But an entrepreneurial university goes beyond this by developing capabilities in capturing and resolving the problems and needs of society as a whole, converting them into new research projects and intellectual paradigms, thereby creating a virtuous circle with internal intellectual development (Todorovic et al. 2011).

This paper looks at how the vocation of universities as entrepreneurial institutions has encouraged, within the Polytechnic Institute of Coimbra (IPC), the organisation of business idea competitions among students and lecturers and business plan competitions. What happened over the period 2008-2014 showed a strong and significant involvement of students and lecturers in spreading the entrepreneurial spirit, the transfer of knowledge/technology, patent registration and business creation.

This article is organised as follows. The introduction contextualises the study and states its purpose. The "Literature review" section briefly reviews the literature on the evolution of the vocation of the modern university and the establishment of companies in an academic environment, while the "The context of the study" section describes the IPC context. The "Methodology and goals" section explains the methods used in the collection and processing of data through a survey of regional finalists' business plans (Poliempreende competition). The "Results and discussion" section presents and discusses the results. The findings confirm that the IPC has the embryonic characteristics of an entrepreneurial university, the promotion of contests for business ideas and plans among its students and lecturers, which resulted in the registration of six patents and the creation of four new companies.

\section{Literature review}

\section{Changing world of academia}

An "entrepreneurial university" may seem a paradox, the antithesis of the "ivory tower" academic model (Etzkowitz et al. 2000). However, a natural consequence of the development towards a knowledge economy has been the transformation of the university such that academic entrepreneurship has become an extension of teaching and research activities and technology transfer resources have become internationalised.

The transition to entrepreneurial university enlarges the traditional academic mission and paves the way for other missions. These changes have created the ability to formally transfer the output of academic R\&D to society. In addition, universities have used their research and teaching abilities in advanced areas of science and technology to create new businesses, while simultaneously expanding their education and training skills to embrace students in programmes to motivate entrepreneurs and the incubation of new firms (Etzkowitz and Leydesdorff 1997; Etzkowitz 2002). In this regard, the capitalisation of knowledge has changed the way scientists view the results of their research, and the entrepreneurial culture assumed by academia now fosters the economic exploitation of the results of their R\&D as well as their intellectual potential (Etzkowitz 1998).

As measures to cultivate the spirit and entrepreneurial culture in universities, the traditional technology transfer offices (TTO) have incentivised academia to take an interest in using the results of its R\&D for marketing and external ventures (Rogers et al. 1999; 
Siegel et al. 2001). The entrepreneurial culture also drives the search for external resources to undertake R\&D projects, and this dynamic also leads to a broader conception of entrepreneurship and mapping of its various forms of commercial, social, cultural, and civic entrepreneurship, where a teaching university can also be the source of new economic activity (Etzkowitz 2014).

Furthermore, entrepreneurial attitudes and skills can be stimulated through entrepreneurship educational programmes (Wang and Wong 2004). So scientists who want the original results of their research to be recognised and to benefit economically can participate in the rewards that may be generated without affecting the academic and business objectives.

Entrepreneurial universities increase their business activities in relation to the commercialisation of research, and established industries may well see them as competitors or partners, probably both at the same time. Certainly, not all universities fit the business model since some focus mainly on teaching or research and are not interested in commercialising any discoveries or participating in social improvement schemes. However, the literature points to a global movement towards the transformation of academic institutions of various kinds, such as teaching and research universities and polytechnics, enabling them to become entrepreneurial universities (Van Looy et al. 2011; Sam and Sijde 2014). The entrepreneurial university thus has a high degree of autonomy to set its own strategic course and engage with other institutional spheres on equal terms to formulate joint projects for economic and social development, especially at the regional level (Etzkowitz 2013; Harrison and Leitch 2010; Mok 2013; Marques 2009, 2014; Svensson et al. 2012;. Van Looy et al. 2011). Thus, we can see the entrepreneurial university as a growing contemporary phenomenon, global in nature, with a pattern of isomorphic development in different regions and countries (Philpott et al. 2011). These changes in academia have sparked scientific interest in understanding the entrepreneurial activity at the Polytechnic Institute of Coimbra, in Portugal. How has the IPC encouraged the spirit of entrepreneurship among the academic community?

\section{Firm creation in academia}

The traditional knowledge marketing model employed by universities is based on the creation of patents through the TTO, the business incubation system, science parks and even on venture capital (Mowery et al. 2001; Nelson 2001). In any case, the aim is to identify knowledge and technology with marketing potential and channel it to the market. In addition, there has been a gradual shift in focus to the process of generating start-ups, both to maximise revenues and to find marketable applications (D'Este and Perkmann 2011).

Technology-based companies are usually created through a business process that has multiple sources. One example is an individual who has a new vision for combining existing elements in a new product or service, or it could be an inventor of a technology with broad scope involving advanced skills (Carayannis et al. 1998; Gibson and Stiles 2000). Other sources, often neglected, include an entrepreneurial process that usually involves people with different skills (Ardichivili et al. 2003; Aviram 2010), with the academic entrepreneur being a key element because the creation of a business start-up reflects individual actions and personal traits such as personality, qualifications, work experience and willingness to engage in commercial activities. 
The figure of the academic entrepreneur has been analysed in the literature, with the focus being on factors such as academic degree, experience, scientific output and social networks, together with the importance of incentives in the context of public policies (Shane 2004; Braunerhjelm 2007; Vohora et al. 2004).

In the academic context, creating firms based on new technology almost always involves technical and commercial partnerships that allow lasting relationships of trust to be built up. The cross-fertilisation of ideas and knowledge between the parties is thus the key to the generation of ideas, while the involvement of lecturers and researchers as collaborators and the availability of funds are stressed as important enablers of firm creation (Van Looy et al. 2011).

Regarding determining factors for and the consequences of creating start-ups, O'Shea et al. (2008), referring specifically to academic start-ups, suggest that this relies not only on the individual characteristics of lecturers and researchers but the differences in university environments and contexts play a part, too. Factors that include engagement in entrepreneurial activity, the characteristics of the universities, e.g. critical mass of researchers, commercial resources and institutional activities, the wider social and cultural context of the university, and external characteristics such as supporting facilities all combine to influence the rate of activity of these new enterprises (O'Shea et al. 2008).

\section{Impact of competition for ideas and business plans}

The literature on competitions for ideas and business plans is relatively scarce. A good number of studies have looked at the importance of education to entrepreneurship in academic curricula (Honig, 2004; Kuratko, 2005; Martinelli et al, 2008). They stress that the entrepreneurial spirit is more than business start-ups, involving as it does educating to exploit opportunities, develop ideas and take risks. Other authors, e.g. Ardichivili et al. (2003) and Aviram (2010), point out that the process of recognising an opportunity is the key to entrepreneurship; they note that opportunities must be built and are not simply found. Van Looy et al. (2011) note that many academic institutions want to foster the entrepreneurial spirit establishing training programmes for business ideas, which educate and train students for entrepreneurship. This partly explains the recent rise in the creation of firms in Europe (Van Looy et al. 2011; Levi 2014).

These arguments have prompted the question, in the case of the IPC, of finding out the impact of the organisation of competitions for ideas and business plans in terms of patenting and creation of start-ups. The research question is based on a previous literature review which highlights the involvement of students and lecturers and the crossfertilisation of ideas with respect to entrepreneurial initiative. Thus, we wanted to find out whether the R\&D undertaken in academia and the involvement of lecturers in business ideas were factors in the registration of patents and the creation of the company. Secondly, we are interested to know if the technology area of the business idea influences patenting.

\section{The context of the study}

Coimbra Polytechnic Institute (IPC) was founded in 1979 as part of the implementation of polytechnic education in Portugal. Although relatively young, the IPC drew on the tradition and the experience of major schools, which began to integrate it to the extent 
that today it is the third largest polytechnic institute in Portugal. Currently, the IPC has 9966 students and 653 lecturers, spread over six teaching units: (1) Escola Superior Agrária (Agricultural College); (2) Escola Superior de Educação (College of Education); (3) Escola Superior de Tecnologia e Gestão (College of Technology and Management); (4) Escola Superior de Tecnologia da Saúde (College of Health Technology); (5) Instituto Superior de Contabilidade e Administração (School of Accounting and Administration); and (6) Instituto Superior de Engenharia (School of Engineering) (IPC 2014).

The high profile that the IPC has gained in the landscape of higher education in Portugal (reflected equally in the large number of students who put its courses as their first choice and in the excellent employment rates of their graduates) is the result of the fine quality of education its colleges and schools deliver. A strong practical component is based on a solid theoretical foundation, not to mention a relentless concern to adapt the courses to the needs of the labour market.

The IPC has evolved gradually from a traditional culture of academia that teaches and pursues research to a more entrepreneurial culture, with technology transfer for patent registration only getting under way in 2013. Seven patents arising outside the Poliempreende competition were introduced between 2013 and 2015, in the areas of "hospital products", "electronic devices", "static gait control" and "optokinetic stimulation device". No spin-off has resulted so far.

The interest in stimulating an entrepreneurial culture among students and lecturers meant that from 2007 the IPC participated in the Poliempreende competition organised for all the Polytechnic Institutes of Portugal. The same competition was promoted at the regional level, intended for students and lecturers, creating favourable conditions for the development of business ideas, knowledge and technology transfer and firm creation. The main goal was to foster an entrepreneurial culture in academia and instil a spirit of initiative in students, a willingness to venture that can lead to the establishment of their own company and job creation, thereby making use of the eminently practical and vocational character of their training.

The Poliempreende competition has three stages: the first is the generation of ideas; the second is a regional competition for business plans for new company projects; the third is the national competition involving the winners of the regional stage. Between 2008 and 2014, the regional competition attracted 68 business plans for new firms submitted by 659 students and 25 lecturers.

Rounding off the entrepreneurial action of the IPC, in 2013, a physical structure called "Inopol" was installed on the campus. It acts as an incubator and entrepreneurship academy to support students and lecturers in the implementation of new projects and ideas, among which are several newly established firms, the fruit of these competitions.

\section{Methodology and goals}

The main purpose of this article is to describe the entrepreneurial activities of the IPC within the organisation of the Poliempreende competition between 2008 and 2014. We are particularly interested in answering three questions:

- What has been the impact of the Poliempreende in terms of registering patents and creating start-ups? 
- Has the R\&D carried out and the participation of lecturers led to the registration of any patents and the creation of start-ups?

- Did the technology area of the idea lead to any patents?

Data collection was based on two sources: (1) the database of the seven editions of the Poliempreende competition, which each year involved organising a competition of business ideas and a competition of business plans; (2) a survey of 22 finalist projects from the seven business plan competitions from 2008 to 2014, for which 20 valid questionnaires were obtained.

The survey was conducted by mail and later confirmed by telephone between November and December 2014 and aimed to find out the following: (1) the business idea; (2) details of the team of promoters (number of students and lecturers); (3) technology area underlying the idea (information and communication technology (ICT), biotechnology, consumer products, industrial products, energy, others); (4) registration of patents; (5) whether the idea was based on R\&D; and (6) creation of start-up after the competition. The value 0 was assigned to a negative response and 1 to an affirmative response.

The dependent variables were the number of patents and the number of start-ups created. These variables are indicators of the entrepreneurial activity of the IPC. The independent variables were the idea being based on $R \& D$, the number of lecturers involved in the competition teams and the technology area of the business idea to be created. These variables are taken as possible causal and explanatory factors for patent registration and firm creation. Figure 1 represents the relationship to study between the dependent and independent variables.

The data was processed with SPSS software, and Fisher's exact test was used for a confidence level of $90 \%$. When possible, the associations were measured using Cramer's V coefficient. The results were interpreted broadly, with an interest not only in showing statistically significant associations but also in detecting general trends of strong associations that might reveal passive tendencies of being potentially explanatory of patenting and new firm creation.

\section{Results and discussion}

The empirical analysis of the sample is divided into three parts: first, a description of the overall results regarding the impact of Poliempreende competition in terms of patenting and firm creation at regional level; second, a discussion of the results of the relationship between the existence of $R \& D$ activities based on the idea and the

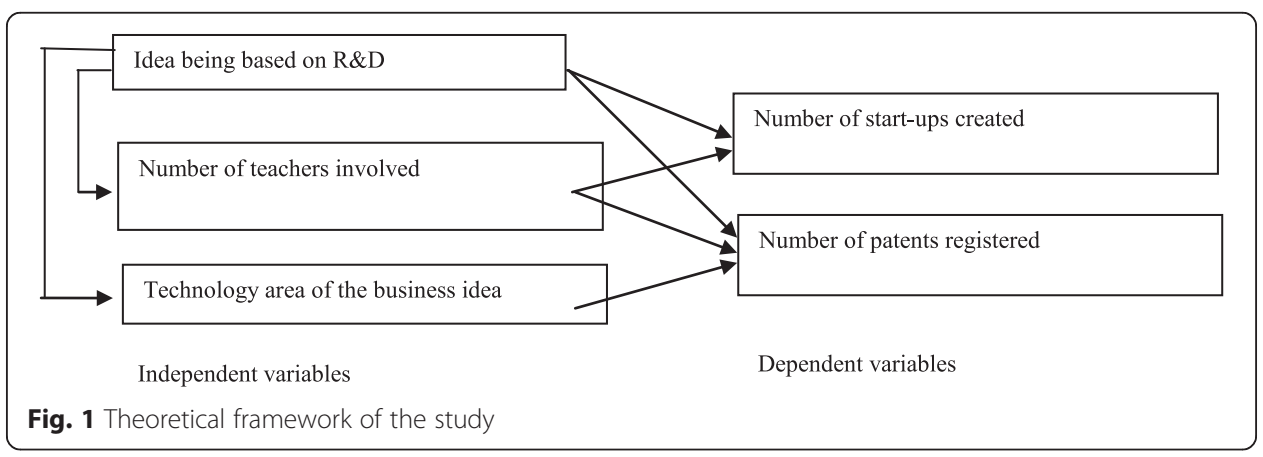


participation of lecturers in the projects and their impact on patenting and on firm creation; third, the relationship between the technology area providing the foundation of the business idea in competition and the registration of patents.

\section{General analysis of the impact of the Poliempreende competition}

The results of the general analysis call attention to the importance of the Poliempreende competition, given the high number of students and lecturers involved in the ideas and business plan competitions and the projects submitted. There were 659 students involved in the idea competition and 238 in the business plan competition. The idea competition precedes the business plan one, and so naturally, fewer projects are prepared for the latter. The total number of business plans submitted for the period 2008-2014 was only 68 . Twenty-five lecturers were engaged on these final projects and 22 business plan projects won awards at the regional stage of the Poliempreende competition. This process made it possible to create a climate that favoured creativity and the generation of ideas among students and lecturers, with the communication of skills in building the business plan and alerting the academic community to the notion of entrepreneurship. It also initiated a change in attitudes and in the academic culture.

Table 1 shows the number of ideas, business plans, participants, patents registered and start-ups created over the 2008-2014 period.

Although the key objective of the Poliempreende competition is to raise the awareness of students and lecturers to entrepreneurship, we tried to measure its impact through the number of patents registered and start-ups created. The results show six patent applications submitted and four firms created, with lecturers being involved in all of them. The patents related to the areas of "regulators of agricultural growth", "orthopaedic biomechanics", "electronic devices for engines" and "micro propagation". The firms operate in the fields of agro-tech, virtual instrumentation and biomechanics. The importance of academic knowledge and technical know-how for project development is thus quite clear.

Of the 20 business plan projects characterised by their underlying area of technology, by $R \& D$ underpinning the business idea and by the involvement of lecturers (Table 2), there were six business plans in the area of biotechnology, five for consumer products and four focused on ICT.

Sixteen of the 20 projects in our study involved lecturers and of these 12 were based on academic R\&D. This supports the idea that the technology areas underlying projects

Table 1 Poliempreende competition (ideas, business plans, participants, patents and start-ups (per year)

\begin{tabular}{llllllllll}
\hline & 2008 & 2009 & 2010 & 2011 & 2012 & 2013 & 2014 & Total \\
\hline Ideas & No. of teams & 25 & 17 & 26 & 25 & 31 & 54 & 28 & 206 \\
& No. of students & 75 & 62 & 78 & 92 & 104 & 159 & 89 & 659 \\
\multirow{4}{*}{ Business plans } & No. of projects & 6 & 6 & 9 & 9 & 13 & 14 & 11 & 68 \\
& No. of students & 18 & 22 & 35 & 47 & 38 & 48 & 30 & 238 \\
& No. of teachers & 2 & 2 & 2 & 5 & 2 & 8 & 4 & 25 \\
& No. of patents & 1 & & & 1 & 1 & 2 & 1 & 6 \\
& No. of firms created & & 1 & & 1 & & 2 & & 4 \\
\hline
\end{tabular}

Source: survey conducted in the study 
Table 2 Poliempreende competition: technological area, R\&D and teachers $(n=20)$

\begin{tabular}{llllll}
\hline Technological area & No. & R\&D underpinning idea & No. & Teachers in projects & No. \\
\hline 1. ICT & 4 & Yes & 12 & Yes & 16 \\
2. Biotechnology & 6 & No & 8 & No & 4 \\
3. Consumer products & 5 & & & & \\
4. Industrial products & 3 & & & & \\
5. Energy & & & & & \\
6. Other & 2 & & & & \\
\hline
\end{tabular}

Source: survey conducted in the study

most likely to win awards and be recognised are biotechnology, consumer products and ICTs, suggesting that the involvement of lecturers and the scientific and technical knowledge of the IPC influences a successful outcome in this competition.

Impact of R\&D and lecturer involvement on the number of patents and start-ups

To answer the second research question, we calculated Fisher's exact test so as to ascertain the impact of having R\&D underpin the idea and lecturer involvement on patent registration and new firm creation.

The findings show (Table 3 ) that having a business idea underpinned by R\&D does not affect patent registration and the creation of start-ups, since the $p$ values are very different from those expected and not statistically significant. The same result was obtained for the association between lecturer involvement and firm creation. A possible explanation could be related to the small number of projects surveyed, since only projects winning awards in the study period were included. However, the association between lecturer involvement and patent registration had a $p$ value of 0.170 , indicating a confidence level lower than desired. Nonetheless, this result does suggest a very significant association since it shows a relatively strong intensity (Cramer $\mathrm{V}=0.4967)$. It is assumed that the greater the number of lecturers involved in business plan projects, the greater the probability of submitting a patent application. This has also been confirmed by the high number of patents arising from the Poliempreende competition-seven patents between 2013 and 2015.

\section{Impact of technology area underlying the idea and number of patents}

As with the previous analysis, we used Fisher's exact test to measure the association between the technological area of the business idea and the number of patents. The result did not show any statistically significant association between these variables ( $p$ value $=0.107)$. However, the intensity is strong (Cramer $\mathrm{V}=0.6204)$ (Table 3),

Table 3 Statistical inference

\begin{tabular}{lllll}
\hline Impact variable & Test & $\begin{array}{l}\text { R\&D undertaken } \\
\text { in IPC }\end{array}$ & $\begin{array}{l}\text { Teachers involved in } \\
\text { the project }\end{array}$ & $\begin{array}{l}\text { Technological area of } \\
\text { the idea }\end{array}$ \\
\hline Patents & $p$ value & 0.325 & 0.170 & 0.107 \\
& Cramer $V$ & 0.3118 & 0.4967 & 0.6204 \\
Start-ups created & $p$ value & 0.619 & 0.462 & \\
& Cramer $V$ & 0.1531 & 0.3700 & \\
\hline
\end{tabular}

The $p$ values relate to Fisher's exact test because of the small number of observations. Source: survey conducted in the study 
suggesting a tendency for an impact of the technology underlying the projects and patent creation, i.e. incentives provided by academia in the areas of biotechnology, ICTs and consumer products could influence the registration of a patent.

\section{Conclusions}

This paper has looked at how the university's vocation as an entrepreneurial institution has encouraged the promotion of competitions for ideas and business plans among students and lecturers, within the Polytechnic Institute of Coimbra. Between 2008 and 2014, there was a strong and significant involvement of students and lecturers in spreading the entrepreneurial spirit, the transfer of knowledge and technology, patent registration and firm creation. The study covered 20 business plan projects that won awards in the regional competition in the period. The results showed the importance of the Poliempreende competition, since 659 students took part in the section devoted to idea generation, while 238 students and 25 lecturers were involved in business plan competitions. The outcome was 68 final projects developed and entered in the competition. The 20 award-winning projects led to six patent applications and four projects developed to create a start-up. The motivating atmosphere of the competitions is undoubtedly the reason for these results, which confirms the studies by Martinelli et al. (2008), Van Looy et al. (2011), Etzkowitz (2014) and Levi (2014), which see the academic environment as a fertile setting for nurturing ideas, entrepreneurship and innovation.

The statistical tests performed indicate that the R\&D undertaken in the IPC does not determine the registration of patents and firm creation, nor is the involvement of lecturers statistically relevant to the creation of start-ups. The results are basically due to the small number of projects surveyed. It is thought that a bigger sample could show that academic R\&D and lecturer involvement are in fact relevant causal variables.

Although no statistical significance of the association between lecturer involvement in the business plan projects and the number of patents was registered, the intensity is strong, suggesting that the greater the cross-fertilisation of knowledge and support from lecturers, the greater the likelihood of registering a patent.

Rather more conclusive was the finding that the technology area of the projects surveyed influenced patent applications, with a strong association being found. These results highlighted the relevance of biotechnology, ICT and consumer products as the technology areas sustaining business plan projects which are decisive for patent registration. This suggests that the IPC has used its teaching and research capabilities in advanced fields of science and technology and is open to transferring its knowledge to the community. At the same time, it has extended its training to students on programmes concerned with fostering entrepreneurship and business incubation, which led to six patents being generated and four start-ups established. This confirms the trends reported by Etzkowitz and Leydesdorff (1997) and Etzkowitz (2002, 2014). These signs further bear out the general shift towards the conversion of academic institutions such as Coimbra Polytechnic Institute into entrepreneurial universities (Van Looy et al. 2011; Todorovic et al. 2011; Sam and Sijde 2014).

\section{Policy implications}

The literature on the impact of incentives for entrepreneurship, such as idea and business plan competitions, on academia is fairly limited. Traditionally, students and lecturers tend 
to focus on academic studies and research, with the exploitation of knowledge and technology for economic ends in third place. This boosts the idea that universities can play an important part in technology transfer activities in their regions. There are thus two practical implications for management.

First, entrepreneurial universities, regarded as instruments to facilitate entrepreneurship through the economic exploitation of $R \& D$, are undoubtedly an appropriate resource for incentivising the entrepreneurial spirit in their students and lecturers. This research has shown that the involvement of lecturers and the staging of competitions for ideas and business plans are vital to the registration of patents. A more thorough examination of these aspects may well help to boost the rates of new firm creation and patent application. Second, from the standpoint of policies to stimulate entrepreneurship, the promotion of competitions for ideas and business plans in academia can be regarded as a strategy to stimulate the entrepreneurial spirit and the registration of patents, thereby leading to the production and marketing of goods and services through new companies.

\section{Limitations and directions for further research}

The research was based solely on projects for business plans that won awards in regional Poliempreende competitions. It would be interesting and useful to extend the study to all the projects submitted and so improve the chance of achieving statistically more consistent results.

\section{Additional file}

Additional file 1: Translation of the abstract into Arabic. (PDF $124 \mathrm{~kb}$ )

Received: 12 September 2015 Accepted: 11 February 2016

Published online: 25 February 2016

References

Ardichivili A, Cardozo R, Ray S (2003) A theory of entrepreneurial opportunity identification and development. J Bus Ventur 18:105-123

Aviram A (2010) Entrepreneurial alertness and entrepreneurial awareness_are they the same? Acad Entrepren J 16(1):111-124 Braunerhjelm P (2007) Academic entrepreneurship: social norms, university culture and policies. Sci Public Policy 34(9):619-631

Carayannis E, Rogers E, Kurihara K, Allbritton M (1998) High technology spin-offs from government R\&D laboratories and research universities. Technovation 18(1):1-11

D'Este P, Perkmann M (2011) Why do academics engage with industry? The entrepreneurial university and individual motivations. J Technol Transfer 36:316-339

Etzkowitz H, Leydesdorff $L$ (1996) The future location of research: a triple helix of university-industry-government relations. EASST Review 15(4):20-25

Etzkowitz H, Leydesdorff L (1997) Universities and the global knowledge economy, a triple helix of university-industrygovernment. Pinter, London

Etzkowitz H (1998) The norms of entrepreneurial science: cognitive effects of the new university-industry linkages. Res Policy 27:823-833

Etzkowitz H, Leydesdorff L (2000) The dynamics of innovation: from national systems and mode 2 to a triple helix of university-industry-government relations. Res Policy 29:109-129

Etzkowitz H, Webster A, Gebhardt C, Terra B (2000) The future of the university and the university of the future: evolution of ivory tower to entrepreneurial paradigm. Res Policy 29:313-330

Etzkowitz H (2002) Incubation of incubators: innovation as a triple helix of university-industry-government networks. Sci Public Policy 29(2):115-128

Etzkowitz H (2008) The triple helix: university-industry-government innovation in action. Routledge, New York

Etzkowitz, H (2013) Can a teaching university be an entrepreneurial university? Civic entrepreneurship and the formation of a cultural cluster in Ashland, Oregon. CIMR Research Working Paper Series.Working Paper N 11. May 1

Etzkowitz H (2014) Making a humanities town: knowledge-infused clusters, civic entrepreneurship and civil society in local innovation systems. Triple Helix J 1:12

Gibbons M, Limoges G, Nowotny H, Schwartzman S, Scott P, Trow M (1994) The new production of knowledge: the dynamics of science and research in contemporary societies. Sage Publications, London 
Gibson DV, Stiles C (2000) Technopolis, technology transfer, and globally networked entrepreneurship. In: Conceição P, Gibson DV, Heitor M, Shariq S (eds) Science, technology and innovation policy: opportunities and challenges for the knowledge economy. Quorum Books, Westport, pp 195-207

Guston H, Keniston K (1994) Introduction: the social contract for science. In: Guston H, Keniston K (eds) The fragile contract. The MIT Press, Cambridge

Harrison R, Leitch C (2010) Voodoo institution or entrepreneurial university? Spin-off companies, the entrepreneurial system and regional development in the UK. Reg Stud 44(9):1241-1262

Honig B (2004) Entrepreneurship education: toward a model of contingency-based business planning. Acad Manag Learn Educ 3(3):258-273

IPC (2014) Instituto Politécnico de Coimbra). http://portal.ipc.pt/portal/portal/sobrelPC/apresentacao. Accessed 20 November 2014

Kuratko D (2005) The emergence of entrepreneurship education: development, trends, and challenges. Entrepreneurship theory and practice. 577-599

Levi J (2014) The university is the classroom: teaching and learning technology commercialization at a technological university. J Technol Transfer 3:793-808

Marques JPC (2009) Business incubators and the emergence of the entrepreneurial university: lessons learned from Portugal. In: Bradshaw MV, Carrington P (eds) Entrepreneurship and its economic significance, behavior and effects. Nova Science Publishers, Inc, New York, pp 113-131

Marques JP (2014) Regional dynamics of triple helix spaces of innovation, knowledge and consensus and the creation of firms in Coimbra (Portugal). Int J Bus Soc Res 3(1):48-60

Martinelli A, Meyer M, Tunzelmann N (2008) Becoming an entrepreneurial university? A case study of knowledge exchange relationships and faculty attitudes in a medium-sized research-oriented university. J Technol Transfer 33:259-283

Mowery D, Nelson R, Sampat B, Ziedonis A (2001) The growth of patenting and licensing by U.S. universities: an assessment of the effects of the Bayh-Dole Act of 1980. Res Policy 30:99-119

Nelson R (2001) Observations on the post-Bayh-Dole rise of patenting at American Universities. J Technol Transfer 26:13-19

Mok K (2013) The quest for an entrepreneurial university in East Asia: impact on academics and administrators in higher education. Asia Pacific Educ Rev 14:11-22

O'Shea R, Chugh H, Allen T (2008) Determinants and consequences of university spinoff activity: a conceptual framework. J Technol Transfer 33:653-666

Philpott K, Dooley L, O'Reilly C, Lupton G (2011) The entrepreneurial university: examining the underlying academic tensions. Technovation 31:161-170

Rogers EM, Hall BJ, Hashinoro M, Steffensen M, Speakman KL, Tinko MR (1999) Technology transfer from universitybased research centers: the University of New Mexico experience. J High Educ 70(6):687-705

Shane S (2004) Encouraging university entrepreneurship? The effect of the Bayh-Dole Act on university patenting in the United States. J Bus Ventures 19:127-151

Sam C, Sijde P (2014) Understanding the concept of the entrepreneurial university from the perspective of higher education models. Int J High Educ Res 68:891-908

Siegel D, Thursby J, Thursby M, Ziedonis A (2001) Organizational issues in university-industry technology transfer: an overview of the symposium issue. J Technol Transfer 26:5-11

Svensson P, Klofsten M, Etzkowitz H (2012) An entrepreneurial university strategy for renewing a declining industrial city: The Norrkoping way. Eur Plan Stud 20(4):505-525

Taylor M (2012) The entrepreneurial university in the twenty-first century. Lond Rev Educ 10(3):289-305

Todorovic W, McNaughton R, Guild P (2011) Entre-U: an entrepreneurial orientation scale for universities. Technovation 31:128-137

Van Looy B, Landoni P, Callaert B, van Pottelsberghe B, Sapsalis E, Debackere K (2011) Entrepreneurial effectiveness of European universities: an empirical assessment of antecedents and trade-offs. Res Policy 40:553-564

Vohora A, Wright M, Lockett A (2004) Critical junctures in the development of university high tech spinout companies. Res Policy 33(1):147-175

Wang C, Wong P (2004) Entrepreneurial interest of university students in Singapore. Technovation 24:163-172

\section{Submit your manuscript to a SpringerOpen ${ }^{\circ}$ journal and benefit from:}

- Convenient online submission

- Rigorous peer review

- Immediate publication on acceptance

- Open access: articles freely available online

- High visibility within the field

Retaining the copyright to your article

Submit your next manuscript at $\boldsymbol{\nabla}$ springeropen.com 